\title{
Safety of aromatase inhibitors in the adjuvant setting
}

\author{
Edith A. Perez
}

Published online: 13 December 2007

(C) Springer Science+Business Media, LLC. 2007

Erratum to: Breast Cancer Res Treat (2007) 105(Suppl 1)

\section{DOI 10.1007/s10549-007-9704-7}

Due to an oversight, Financial Disclosure of the Authors in the above referenced supplement was not published as required. All authors have acknowledged and signed a statement of Financial Disclosure/Conflict of Interest and certify that no honoraria for the work therein were received.

The online version of the original article can be found under doi:10.1007/s10549-007-9704-7.

E. A. Perez $(\bowtie)$

Mayo Clinic, 4500 San Pablo Road, Jacksonville, FL 32224,

USA

e-mail: perez.edith@mayo.edu 